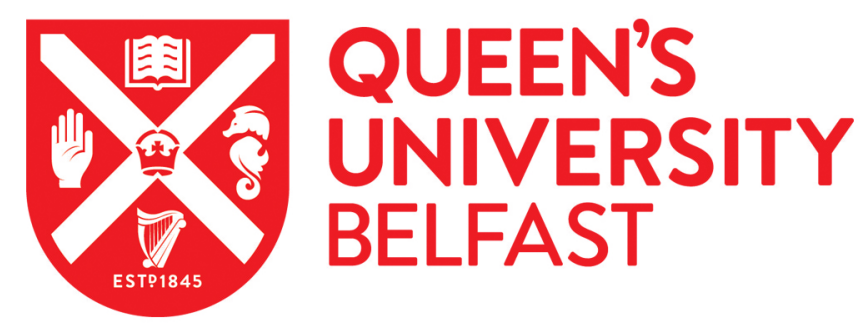

\title{
The New Year's 2015/ 2016 Public Sexual Violence Debate in Germany: Media Discourse, Gendered Anti-Muslim Racism and Criminal Law
}

Vieten, U. M. (2018). The New Year's 2015/ 2016 Public Sexual Violence Debate in Germany: Media Discourse, Gendered Anti-Muslim Racism and Criminal Law. In M. Bhatia, S. Poynting, \& W. Tufail (Eds.), Media, Crime and Racism (1st ed., pp. 73-92). (Palgrave Studies in Crime, Media and Culture). Palgrave Macmillan.

Published in:

Media, Crime and Racism

Document Version:

Peer reviewed version

Queen's University Belfast - Research Portal:

Link to publication record in Queen's University Belfast Research Portal

Publisher rights

(C) 2018 Palgrave Macmillan.

This work is made available online in accordance with the publisher's policies. Please refer to any applicable terms of use of the publisher.

\section{General rights}

Copyright for the publications made accessible via the Queen's University Belfast Research Portal is retained by the author(s) and / or other copyright owners and it is a condition of accessing these publications that users recognise and abide by the legal requirements associated with these rights.

Take down policy

The Research Portal is Queen's institutional repository that provides access to Queen's research output. Every effort has been made to ensure that content in the Research Portal does not infringe any person's rights, or applicable UK laws. If you discover content in the

Research Portal that you believe breaches copyright or violates any law, please contact openaccess@qub.ac.uk. 


\title{
(1)

\section{The New Year's 2015/2016 Public Sexual Violence Debate in Germany: Media Discourse, Gendered Anti-Muslim Racism and Criminal Law}

\author{
Ulrike M. Vieten
}

Sex-Attacke im Freibad auf 10-Jaehrige-Onkel des Opfers schlug Afghanen (headline) ${ }^{1}$

\section{Introduction}

The New Year's Eve 2015/2016 sexual attacks on non-migrant women in German public spaces near the main train stations in Cologne and Hamburg, but also in Stuttgart, have triggered far-right populist debates on the 'integration and gender equality skills' of new immigrants and North African male refugees, ${ }^{2}$ in Germany and elsewhere. According to Yilmaz (2015: 38), 'The dichotomous constellation of cultures with gender and sexuality as baselines is symptomatic of the way sociopolitical divisions are imagined, and acted upon, in public discourse.'

Media coverage following the sexual attacks in different cities signify largely an overall moral panic and increase in racialising Muslim men of

U. M. Vieten $(\bowtie)$

Queen's University Belfast, Belfast, UK

(C) The Author(s) 2018 
Middle East descend, expressing a new scale of 'global Islamophobia' (Morgan and Poynting 2013).

The international public outcry initiated by what appeared to be systematic sexual attacks combined with theft offenses by visibly different, minority men on New Year's Eve 2015/2016 prompted contestations about feminist responses ${ }^{3}$ to it and the need to think sexism and racism as intersecting social structures of oppression. ${ }^{4}$ Further, the events started a wider debate in society: it pushed the reform of criminal law in Germany, ${ }^{5}$ extending the framework of what is regarded as an individual (female) right of sexual autonomy, ${ }^{6}$ defined in paragraph 177 STGB. Also, the institutional side of how police reacted initially to the situation on the 31 December became subject of an official inquiry in North Rhine Westphalia (NRW), the federal land of the two cities, Cologne and Dusseldorf. The purpose of this public commission is to interrogate the role of the police in the unfolding of the events. ${ }^{7}$ I tried to get hold of records and documents, but this was not possible as this is an inquiry in process.

This chapter discusses some of the national and international media coverage of the New Year's Eve 2015/2016 sexual attacks, and the political, legal and societal responses to it in the period January to July 2016. With this reflection it contributes to international debates on Islamophobia, Anti-Muslim racism and gender (Fekete 2004; Morgan and Poynting 2013; Nelson 2015).

In terms of terminology, I prefer using 'racialising' here in order to emphasise that others are discursively racialised and that racialising is not limited to post-slavery and post-colonial 'race' discourses (Vieten 2011). Arguably, Islamophobia has to be linked to racism as it describes the way Muslims became racialised, particularly post 11 September 2001 (Vieten 2007, 2012; Garner and Selod 2015).

In order to draw on a range of resources in this analysis, I used key words ('Cologne sexual attacks,' 'New Year's Eve 2015/2016,' 'New Year's Eve sexual attacks') while turning to the search engines, 'Google' and 'Bing' (period January to July 2016). Further, I followed the German weekly newspaper, die ZEIT, with its coverage of the New Year's Eve events, between January and July $2016 .{ }^{8}$ In addition, I included publications by state bodies, critical journalists and feminist activists on this topic. 
Using these resources I look at the scandalising of public sexual violence against women recently in Europe (e. g. Germany). It is argued that we are confronted with a gender sensitive but also racist populist outrage on the background of a nativist perception of women as 'German women.'

As it turns out we are confronted with a dilemma: on the one hand, media plays a framing role in displaying, repeating and accelerating racial profiling of Muslim men as potential and actual perpetrators; on the other, media and public outrage pushed the reform of the 177 STGB in Germany. The latter is demanded by feminist activists and lawyers for a long time, and in that regard the 'moral panic' strengthened the feminist argument and support for a revision of criminal law (e.g. 'sexual autonomy').

First, the phenomenon of 'public sexual violence' is contextualised by looking at social spaces where gendered sexual violence takes place, and asking to what degree public sexual violence in Europe is a new phenomenon. Second, the chapter looks at how gender and Islamophobia relate to each other and focuses on the ways the New Year's Eve attacks have to be read against gendered culturalism and racism in Europe. Finally, the media coverage will be scrutinised while investigating patterns in the way victims and perpetrators are portrayed, trying to understand how criminal investigators, courts and civil society in Germany dealt and deal with the issue of mass public sexual violence. Here, I will also refer to an expert statement of feminist lawyers in North Rhine Westphalia (NRW), published in direct response to the New Year's Eve sexual offenses.

\section{Gendered Violence: The 'Private' and 'Public' Dimension of Sexual Violence Against Women}

Feminists have engaged with institutionalised, everyday sexism ${ }^{9}$ and the problematic boundary of the private and the public sphere (see, e.g. McDowell 1983; Fraser 1990; Walby et al. 2014) in terms of gendered violence since the 1970s. The continuity of sexual violence against women, primarily taking place in the domestic sphere, ${ }^{10}$ indicates that it is an everyday phenomenon that has been tackled in recent decades but still is endemic and far from been eradicated. A British study, released in 
2016, confirmed that slightly more than $50 \%$ of women are harassed at work, which includes 'groping, sexual advances and inappropriate jokes. ${ }^{11}$ Sexual violence has to be understood as part of a wider notion of violence against women: according to the World Health Organisation (WHO) some $35 \%$ of women experience violence, ${ }^{12}$ and thus, it is a global health problem impacting communities and countries beyond the individual cases. Historically, the societal discourse shifted several times since the 1970s: domestic male violence against women was classified among others as caused by 'mental illness,' as 'learned behaviour,' as 'caused by alcohol' or as 'both men and women contribute to violencevictim provocation' (Cavanaugh 2012; Ali and Naylor 2013; Bates et al. 2014; Turchik et al. 2016).

It seems the 'relationship' element dominates cases of domestic sexual violence and contrasts to what might be understood as the defining element of public sexual violence, for example, sexual attacks by a stranger. The latter is politicised in the current debate and does need further reflection: to what extend is public sexual violence only been noted recently in European societies, for example, in the context of the emergence of mass immigration of refugees from the Middle East? Having said that it seems that mass expression of group male violence against women was first documented in Egypt, in 2005 (Amnesty International 2015: 10). According to Amnesty International (2015) 'in recent years, sexual assaults in public have surged, with women and girls increasingly targeted by groups of men and boys, often at political demonstrations, but also during other large public gatherings ... Egyptian human rights organizations have reported that have documented over 500 cases of gang rape and sexual assaults between June 2012 and 2014' (9-10). Though it is reported in Egypt that these acts of public sexual violence also happen at 'religious festival and large public gatherings,' the context of the 'Arab Spring' and the significance of the Tahrir Square protests in 2012 introduce a more systematic way of using sexual violence against independent and politically left-wing women at political demonstrations.

Mancini and Pickett (2016: 259-260) pinpoint that women and children are regarded as a particularly vulnerable victim group impacting on the wider public view how to punish the perpetrator. They argue 'It is likely that offenses against this victim base trigger intense moral emotions 
and, in the public's view, cannot extend from "normal" motives, such as economic gain or interpersonal anger, and thus those who commit them cannot be normal individuals.' Further, they add, 'there is a widely endorsed perception that victims are at substantial risk of being assaulted by stranger perpetrators, a view of reflecting the myth of "stranger danger" (Craun and Theriot 2009).'

Accordingly, the 'stranger danger' is a widely held view in the context of sexual violence. As far as domestic and interpersonal sexual violence is concerned, perpetrators are predominantly male and mostly live in close and private proximity to their victims. In terms of the phenomenon of 'public' sexual violence, the myth of the 'stranger danger' does not hold though: here we are talking about the attack of a stranger. It appears the contemporary fear of the oriental stranger needs further interrogation while acknowledging that the stage of public violence, including sexual violence against women, might have reached a new dimension in Europe as elsewhere.

Following the data of the FRA (European Union Agency for Fundamental Rights) ${ }^{13}$ 'sexual violence is "an extensive human rights abuse" across Europe. One in three women reported some form of physical or sexual abuse since the age of fifteen. More than half of all European women, including sixty percent of German women, reported that they had experienced sexual harassment or stalking since the age of fifteen. Only thirteen to fourteen percent of the women surveyed across Europe reported their worst incident of partner or non-partner violence to the police.' Though the overall findings confirm the 'personal relationship' aspect and echo the dominance of 'domestic violence,' the report also stresses that ' $53 \%$ of women in the EU avoid certain situations or places, at least sometimes, for fear of being physically or sexually assaulted' (2014). Stalking and cyber harassment as forms of sexual violence are on the rise, too. However, according to this study there is a huge lack in reporting 'publically' experienced sexual violence (ibid.). Overall sexist perceptions affect in significant ways the willingness of women to report cases of sexual violence to the police as far as semi-private and public spaces are concerned. ${ }^{14}$

Further questions result from the outcome of this study, and from broader perceptions of what does count as a sexual attack and how woman 
(individually) has to respond to it: to which degree is the notion of 'public' sexual violence dismissed in the German, and wider European, contexts for decades, or, to put it differently, did it remain rather under reported as a criminal offense? Is it true that public sexual violence targeting women and young girls as a mass phenomenon is that 'new' as Hannelore $\mathrm{Kraft}^{15}$ argued? And further, what is the situation for Muslim women in this regard; are they included as female victims in similar ways?

Next, I will look at the perceived 'newness' of public sexual violence in Germany. This has to be read against the notion of 'consent' as embedded in institutionalised sexism: is there a notorious perception of what female acceptance of the act itself means, and what a male perception of that 'consent' in the act, implies actually? Further, I will relate the gendered culturalist discourse and anti-Muslim racism in Germany and elsewhere to a more symptomatic lack of reported cases of public sexual violence. I argue that Muslim men are grouped and blamed as potential sexual attackers in the public eye falling short in acknowledging a general problem of a rise of male violence in public spaces.

\section{The October Fest or Taharrush? Place, Crime, Ethnicity and Gender}

Following the New Year's Eve attacks, national as well as international media jumped quickly on the idea to link Cologne to the Egypt mass phenomenon of sexual attacks on women, called Taharrush, an Arabic term for 'harassment' that is identified with it. Abdelmonem et al. (2016) argue:

Reflecting these same notions with regards to the New Year's Eve attacks, the New York Times reported that in Cologne "groups of young men began encircling young women." Citing Welt am Sonntag, Deutsche Welle stated, "A group of young men would encircle the female victim, close the loop, and then start groping the woman." In a Bloomberg News wire piece reprinted in the Chicago Tribune, the coverage highlighted how politically commissioned sexual harassment and assaults in Egypt derived from a historical cultural practice of sexual harassment. By situating 
politicized violence within a "long-standing culture of treating lone women as acceptable targets for harassment" this news agency drew distinctly cultural conclusions about the Arabized and Islamicized "nature" of sexual violence in the Cologne assaults. By means of this associative framing strategy, the coverage managed to align two separate circumstances of sexual harassment and assault and to portray them as manifestations of the same process of collective sexual violence.

Labelling and linking mass sexual violence in Cologne and Hamburg, for example, to attacks in Egypt suggests to the public it might be an 'import' by Middle East and North African/Arab men. Abdelmonem et al. (ibid.) stress that this narrative of the oriental male attacker (oppressor) was employed when making the case for militaristic interventions back to the pre-war rhetoric to interfere in Afghanistan, in 2003. Back then (as today), it was the oppressive regime of the Taliban that triggered a broader international consensus to justify the USA-UK ${ }^{16}$-led war coalition. As argued elsewhere (Vieten 2012: 34).

"The non-veiled Western modern woman symbolizes the "positive" in contrast to the "negative" image of the veiled woman.' (Vieten 2011: 69) Either way the secular modern nation state and the orthodox religious community are claiming the female body as a gendered symbol of 'their' community (Gemeinschaft). However, this indicates how woman in terms of bio-politics (Foucault) is considered patriarchal property (ibid.). It is worth noting too, that the French debate on the headscarf was engendered by President Chirac in 2003, explicitly referring to a national identity crisis torn between the republican 'laicite' and 'the citizens' of Europe.'

Within a period of 15 years, post 11 September 2011, gendered culturalism and anti-Muslim racism have become normalised in different societies across Europe, particularly in the Netherlands (Vieten 2017), but also in neighbouring European countries such as France or Germany (Vieten 2016). After years of discursively constructing an essentialist and orientalist 'cultural-ethnic' boundary between the Judeo-Christian Occident and the oriental Muslim Other (Vieten 2011, 2012), the new far right takes a by and large mainstreamed 'common sense' racism, to more extreme levels. 
This culturalism encompasses mainstream Islamophobic views (Wodak 2013; Wodak and Reisigl 2015), and has turned into a "normalised" gendered lens to view religious-cultural group differences. That means culturalist gendered projection became "normalised" in a few years, and turned into a hegemonic lens yet before far right parties gained significant ground in parliaments across Europe (Vieten 2017).

Whereas the New York Times, Deutsche Welle or the Chicago Tribune might count as mainstream liberal media, far-right press uses also blogs and social media to further and install more fear and panic in the audience. In a blog entry, Gatestone Institute ${ }^{17}$ Fellow, Soeren Kern (2016, March 5), 'informs' the public about sexual attacks by migrants in Kiel ${ }^{18}$ referring to police records. Kern argues that the police officially was instructed not to link sexual assaults directly to the ethnic and national background of current refugee groups. And by that he suggests that the police acts on behalf of a liberal political elite that shies away from the rising levels of crimes, for example, sexual violence against women, enacted by migrant, refugees and other visibly different minority men.

The news coverage in the Kieler Nachrichten, 29 February 2016, however, cited different eyewitnesses, who despite confirming that two Afghan men were stalking the girls, clearly stated that the situation was under control and as people were watching also being prepared to intervene. In addition, the police did not receive an actual report of a sexual attack. ${ }^{19}$

It is here where the imaginary of the far-right and nativist mind comes in while generalising individual sexual harassment or stalking as a mode of a culturalist male habit of the Arab foreigner. A racist pattern emerges when sexual violence against women as an everyday phenomenon, introduced above, is mainly problematised in the context of the non-white, non-Christian/stranger attacker. In July 2016, the German Television Broadcast (Allgemeiner Deutscher Rundfunk/ARD) aired a documentary looking more closely at the situation of crime investigations in Hamburg, following the sexual attacks. According to official records in Hamburg, 1200 female victims came forward, and the investigators estimated 2000 perpetrators. The juridical procedures, however, indicate that it is almost impossible to get hold of individual perpetrators due to the lack of proof. $^{20}$ 
Far-right leaders such as Geert Wilders, the leader of the Dutch PVV (Partij Voor de Vrijheid; Freedom party), and Marine Le Pen, leader of the French NF (Front National), also used the Cologne attacks to make a case for their readiness to defend women's rights. The discussion in Germany also echoes this 'new feminist consciousness': Niejahr (ZEIT online, 4.2.2016) calls this 'Femonationalism'; politicians of the centre right (CDU) out of the sudden felt the need to talk about women's rights. According to Abdelmonem et al. (2016), 'By co-opting feminist demands for women's emancipation and their right to self-defense, these conservative forces instrumentalize the Cologne sexual assaults for their xenophobic ends.'

Given the discursive production and co-construction of far-right and mainstream liberal media on this topic, it seems to be relevant to trace how 'public sexual violence' has been reported before 31 December 2015. Also, in concordance with a rather novel fury about public sexual violence against women in Germany and Europe, we might wonder whether there have been similar 'moral panic' outrages reported, too, following sexual violence at public entertaining events, such as the annual Munich October Fest, the Rhineland Carnival in Cologne, Dusseldorf or Mainz or festivals elsewhere?

In an interview with a feminist activists in Munich, for example, it turned out that sexual violence on the Wiesn ${ }^{21}$ has been registered over years; the interviewed activist described a rise in numbers of women asking for help and argued that we have to take into account a dark figure (Dunkelziffer) as most women are ashamed and do not turn to police for further investigation, ultimately not aiming for a penalty of the perpetrators. The number of their clients (women) rose from 12 to 200 in 12 years (TAZ, 16.1.2016).

In 2012, feminist help groups noted a rise of $40 \%$ more victims in comparison to 2011. ${ }^{22}$ As far as Britain is concerned, music festivals also have a reputation of becoming highly sexualised and unsafe spaces for women. ${ }^{23}$ According to Walby et al. (2014: 193), 'Gang theories of violence have been proposed' in criminology and sociology, previously. While referring to Wolfgang and Ferracuti (1967) here, Walby et al. state that 'there may exist a normative acceptance of violence in some societal groups (Wolfgang and Ferracuti 1967). Such values are transmitted 
within the cultural groups and individuals can also be born into such a subculture' (Walby et al. 2014: 193).

Walby et al. (ibid.) admit that these theories have been discredited as they were associated with specific visible minority groups, for example, men; however they underline, too, that Wolfgang and Ferracuti (ibid.) also 'identified class as a relevant societal group' (ibid.).

Despite the controversy it sparks, this is a relevant angle for further consideration as it allows to look more closely at intersecting dimensions of gender, class, religion, sexuality and age, for example, and the way 'subcultures' of violence might be generated. In this context, further investigation is needed to understand to what degree cyber space, internet and social media support a new scale of orchestrated public assemblages. These assemblages offer unguarded public spaces for 'spontaneous' mass sexual attacks. As far as Germany is concerned, media and public opinion agree that this kind of enacted public mob mass attacks were a new phenomenon (ZEIT online, 6.1.2016), and there exists no valid resource and research that proves this wrong.

The news coverage discussed so far refers to women as victims; however, attention is payed only to 'native' women, for example, non-migrant and white women. What does media and research say about the experience of migrant women and, particularly, Muslim women when it comes to sexual harassment and violence in semi- and public spaces?

\section{All Women the Same? The Lack of Acknowledging Muslim and Minority Women as Victims of Public Violence}

Little is known about sexual violence against migrant and refugee women in German public spaces. However, the news coverage on sexual attacks in refugee shelters sheds some light on the presence of male violence. ${ }^{24}$ Though the European Union issued a directive in 2013 (Directive 2013/33/EU), ${ }^{25}$ asking Member States for a special protection of women and children, shelters are predominantly provided as unisex spaces. Mass accommodations probe to be spaces, semi-public though, where 
increasing numbers of female refugees experience harassment and sexual violence not only by other male refugees but also by guards.

More than 440,000 people applied for asylum in Germany last year, with roughly a third of them being women and girls. ... Little is known in Germany about the extent of violence against refugee women and there has been little research into the issue. In one of the few studies that has been undertaken, four out of five respondents said they had been the victims of psychological violence with every second woman saying they had suffered physical violence. The study is now more than 10 years old, but experts believe it is improbable that the numbers have sunk since then. In addition to other refugees, the perpetrators also include security personnel, caregivers and volunteer helpers, all of whom can take advantage of existing structures to easily approach their victims. (Der Spiegel, 11 May 2016)

In a move to change this situation, the German government promised about $€ 150$ million to equip refugee accommodations with more safe spaces for women and keeping a closer eye on how to protect women and vulnerable children in these state-run institutions. The 'Women's Refugee Commission' released a report ${ }^{26}$ in 2016; unlike the situation of 2015 when about $70 \%$ of refugees were male, recent figures show that about $60 \%$ are women and children. Sexual violence (Sexual and Gender-Based Violence/SGBV) occurs on the journey to and through Europe and is not only limited to the experience in the country of origin (2016: 8).

In general, the reporting and thus official records of violence and sexual violence against minority women, migrant women and female refugees lack reliable figures. Another study was released in 2016: 'Forgotten Women: The impact of Islamophobia on Muslim Women,' commissioned by the European Network Against Racism (ENAR). The authors admit that when it comes to violence against Muslim women or racist crime, official data (statistics) is very limited. Apart from a situation where intersecting dynamics of violence are not fully understood and therefore underreported and researched, for example, in the case of hate crime, cases are not often registered as proper complaints (France), are not recorded as an Islamophobic crime and/or the aggravated factor is not recognized (Germany)' (2016: 9). 
The ENAR study refers to racist and sexist violence, ${ }^{27}$ but sexual violence is not included here. However, the physical and intimidating violence against visibly different and orthodox Muslim women, for example, particularly those wearing a headscarf, takes place in many European as well as German public spaces. As the study makes clear, 'attacks are mostly perpetrated by unknown males' (2016: 26).

A well-known case from Germany might illustrate a tendency to ignore intersecting angles of gender (female), religion (Muslim), ethnicity (minority nationality-Egyptian) and class (middle class - student of pharmacy) divisions feeding a combination of lethal sexism and racism: the 31-year-old Marwa El-Sherbini was stabbed in a court in the city of Dresden, in 2009. El-Sherbini had made a legal effort to sue an ethnic Russian, Alex Wiens, who held German citizenship. Wiens had insulted El-Sherbini for wearing a headscarf and murdered her in court during the trial. ${ }^{28} \mathrm{He}$ was sentenced to life for murder and attempted murder (Okaz, El-Sherbini's husband) later on. Though this criminal case hit international news, national and local responses rather focused on court security and less on the racist motives of the attacker. Besides, the police shot at El-Sherbini's husband, Okaz, mistaking him for the attacker. Okaz while trying to protect his wife was stabbed several times by Wiens, but unlike his wife survived.

This public violent attack links to a violent history of racist arson attacks in the early 1990s, post-German unification in 1989: in Mölln (23 November 1992) and Solingen (29 May 1993), women and girls died in the fire flames. "These racist murders provided a landmark within the trauma of many "new" Germans from a Turkish or Kurdish background' (Vieten 2016: 125).

Media had played and continues to play a biased card in the game of 'news' coverage when it comes to sexist and racist thoughts as well as activities. In the 1990s, in the 2009-2011 years (e.g. Sarrazin scandal; see Vieten 2016: 127) as well as in the current moment of 2016, (social) media mirrors dominant gendered and culturalist perceptions. It seems public gendered violence against minority, for example, Muslim women are less acknowledged as an established 'normality' in Germany.

However, the issue of 'sexual' public violence as outlined above is more problematic and cannot be easily subsumed to an affair of either 
'minority' or 'majority' ethnic women. The legal framework operates in line with sexist and culturalist stereotypes: criminal law poses particular problems when it comes to track, testify and trial sexual violence against women, and this refers to majority and minority women likewise. The notion of what does count as 'sexual autonomy' is embedded in societal contexts that are channelled through sexist institutions. These sexist institutions are interwoven and framed by racist and racialising state ideologies (Goldberg 1993, 2002).

The final section will look more closely how German criminal law defines the gendered roles of victims and perpetrators as far as perceptions and roles in sexual activity are concerned.

\section{The Criminal Law Debate: Women and 'Sexual Autonomy'}

As introduced in the beginning of this chapter, the New Years' Eve 2015/2016 attacks initiated among others a wider public and political debate about a much needed reform of Criminal Law in Germany. The German professional association of feminist lawyers ${ }^{29}$; the DJB (Deutscher Juristinnenbund-German Association of Female Lawyers) acted as an expert group in the hearing of the Committee mentioned above. The hearing took place at the federal state parliament of North Rhine Westphalia, in June 2016.

The $D J B$ argued in detail why the immediate political rush to promise to the public a persecution of the individual perpetrators was due to fail. According to the legal experts, it is the character of these sexual attacks in the public domain, which is not taken into account and regulated in existing Criminal Law.

It is likely that a significant percentage of the reported cases cannot be penalized according to current law. This is due to a situation where the facts of the case indicate that the attacks were "unexpected" and therefore no "resistance" against the attacker could have taken place. Otherwise, the attacks might not even qualify as "substantial" in terms of the requirements of Criminal Law. Besides, and following here the details that were publi- 
cized in the media it might be difficult to get a more adequate understanding of the concrete facts. ${ }^{30}$ (Brief Statement of the DJB, 29 June 2016).

According to the old version of Paragraph 177 STGB, the perpetrator must have used what is called in legal terms 'a qualified means of harassment, e. g. force (physical), or an actual (present) threat to the life of the victim, or exploiting the unprotected situation the victim was in; with regard to the latter it is essential that the victim could not resist due to her defencelessness.' ${ }^{31}$ Highly problematic is the sequential link between 'threat' and the sexual assault or rape that might follow afterwards. Also, paragraph $184 S T G B$ requires a certain substantial level of force or actual threat, and as the DJB lawyers made clear some of the temporary insults and harassment ('flüchtiger Griff in the Kleidung oder an den Po'-'a volatile reach into the clothes of a woman, or at her bottom') might not even cross this level ('Erheblichkeitsschwelle').

Further they declared that feminist lawyers were demanding the change in positive law for years. Criminal Law fundamentally tends to ignore the sexual autonomy of women or any vulnerable person. The DJB asked for legislative change already in $2011^{32}$ and drafted a legislative proposal in 2014. Also, they criticised the notion of 'normal' expectations and 'normal cases': the 'normal case' inscribed in law is that the victim would take measures against the attack, and the attacker-perpetrator would take for granted a consent if the victim does not put up a fight (ibid.).

While challenging populist views, media representation and false promises by politicians, the $D J B$ like other feminist activist groups demanded a change of paradigms when it comes to the way female 'sexual autonomy' is approached in society and, as its last resort to defend it, in criminal law.

In April 2016, the second chamber, the German Bundesrat, discussed the legal proposal to change 177 STGB. ${ }^{33}$ Accordingly, the Criminal Law was changed, on 10.11.2016. ${ }^{34}$

Apart from 177 STGB, it includes further new paragraphs, $184 j$ and 184 i STGB, addressing explicitly sexual attacks of groups and that relate to group assemblages. The incorporation of these new paragraphs has to be regarded as a direct legislative response to the media, social and public debate following the New Years' Eve 2015/2016 events. 
Though this sounds positive and could be celebrated as a success to feminist demands, we have to be sceptical to which degree these legal changes combat existing institutional sexism and racism. Certainly, the wider public debate following New Year's Eve 2015/2016 put uncomfortable questions on the table for legislators and the broader society. The more complex dimensions and gendered dynamics of anti-Muslim racism and Islamophobia are not settled by the Criminal Law reform.

\section{Conclusion}

As argued in this paper, the consequences of the New Year's Eve 2015/2016 public sexual violence occurrence in Germany ${ }^{35}$ are multiple and complex: media coverage, but also discussions and material from social media tools, developed quickly after the events and stirred a racialising of Muslim and Arab men. The controversy about the new character of public sexual attacks also pushed wider debates about the sexual autonomy of women. This led to the actual reform of sexist Criminal Law (Paragraph 177 STGB) that was demanded by feminist groups for years. Still, the dominant profile of the perpetrators as presented in media and public discourse is that of a cultural Other and that of the victim as belonging to the native and ethnic German population. Here, intersecting gendered dynamics of racism and sexism as traced in the public discourse leave aside the particularly vulnerable position of Muslim and minority women.

Though individual and group-led sexual attacks have been noted beforehand, in Germany and elsewhere, these particular events introduced a new phenomenon of mass sexual attacks in Europe. Though it is important not to shy away from how these attacks happened and how to create safer public spaces in future, the actual prosecution of individual perpetrators is complicated. Previously, German criminal law was not sufficiently regulated here, and despite its amendments now in 2016, it is not clear to what degree this will help the case. After all, we have to be cautious that proving someone's guild and using established criminal law might be extremely difficult; profiling, finding the individual perpetrator based on the victim's descriptions and memory, is confronted with a climate and society where loose characterisation such as 'darker skin, eyes 
and hair' count for all and nothing. The perpetrator's profiling is a reflection of already existing racial and ethno-national stereotypes. At best, the criminal system subscribes to an ethos of 'in doubt pro innocent person' (in dubio pro reo); at worse, racial stereotypes are used as the base for judgement and punishment.

\section{Notes}

1. WIEN heute, kostenlose Tageszeitung, 12.7.2016; text means: 'Sex attack in swimming pool on a girl of ten years - the uncle of the victim beat the Afghan.'

2. Writing in July 2016, it turned out only a minority of three men who have been traced by police were refugees; however the majority of attackers have been of Moroccan, Tunisian and Algerian background. http:// www.independent.co.uk/news/world/europe/cologne-only-three-outof-58-men-arrested-in-connection-with-mass-sex-attack-on-new-yearseve-are-a6874201.html

3. http://www.vice.com/en_uk/read/rape-culture-germany-cologne-newyears-2016-876

4. http://www.spiegel.de/international/germany/german-feminists-debatecologne-attacks-a-1072806.html

5. https://www.juris.de/jportal/portal/page/homerl.psml?nid=jpr-NLSFA DG000716\&cmsuri=\%2Fjuris\%2Fde\%2Fnachrichten $\% 2$ Fzeigenachri cht.jsp

6. http://dip21.bundestag.de/dip21/btd/18/090/1809097.pdf

7. https://www.landtag.nrw.de/portal/WWW/Navigation_R2010/030Parlament-und-Wahlen/015-Ausschuesse-und-Gremien/030Untersuchungsausschuesse/PUAIV/Inhalt.jsp

8. http://www.zeit.de/suche/index?q=massenhafte+sexuelle+Gewalt+gegen + Frauen $\&$ type $=$ article $\&$ type $=$ gallery $\&$ type $=$ video

9. http://everydaysexism.com/

10. Just put the word 'domestic violence' into an internet search engine (e.g. Google) on 10 August 2016 with 98,200,000 results in 0.43 seconds.

11. https://www.theguardian.com/lifeandstyle/2016/aug/10/half-ofwomen-uk-have-been-sexually-harassed-at-work-tuc-study-everydaysexism

12. http://www.who.int/gho/women_and_health/violence/en/ 
13. http://fra.europa.eu/en/publication/2014/violence-against-womeneu-wide-survey-results-glance

14. I am not going to focus on 'domestic violence' here.

15. Hannelore Kraft is the Social Democratic Minister of North Rhine Westphalia: http://www.n-tv.de/politik/Kraft-entschuldigt-sich-beiSilvester-Opfern-article18094201.html

16. It might be worthwhile to mention that Spain and Poland were also involved whereas Germany (Chancellor Schroeder) was reluctant to join the 'war of the willing,' mainly because of the German history and a moral reluctant to engage in warfare. That said 'morality' seems not that much to matter when it comes to international warfare industry.

17. https://www.gatestoneinstitute.org/

18. http://www.kn-online.de/News/Nachrichten-aus-Kiel/NachBelaestigung-im-Sophienhof-Kiel-Einkaufen-unter-Polizeischutz

19. http://www.kn-online.de/News/Nachrichten-aus-Kiel/Belaestigungim-Sophienhof-Die-Polizei-muss-sich-korrigieren

20. http://www.zeit.de/gesellschaft/zeitgeschehen/2016-05/silvesteruebergriffe-koeln-prozess

21. http://www.taz.de/!5268871/

22. http://www.thelocal.de/20121004/45349

23. http://www.telegraph.co.uk/women/womens-life/11822420/BestivalUK-music-festivals-have-a-rape-problem-that-needs-action-now.html

24. http://www.spiegel.de/international/germany/refugee-hostels-ingermany-beset-by-sexual-assault-a-1091681.html

25. http://eur-lex.europa.eu/legal-content/en/TXT/?uri=celex $\% 3 \mathrm{~A} 320$ 13L0033

26. http://www.unhcr.org/569f8f419.html?utm_source=Joint+UNHCRUNFPA-WRC+Press+Release+-+20+January+2016+-+Report+warns+re fugee+women+on+the+move+in+Eu\&utm_medium $=$ email $\& u$ tm term=Hauenste@unhcr.org\&utm_content=http $\% 3 a \% 2 \mathrm{f} \% 2 \mathrm{fwww}$. unhcr.org\%2f569f8f419.html\&utm_campaign=

27. The study also covers 'discrimination at the work place.'

28. https://www.theguardian.com/world/2009/jul/07/german-trialhijab-murder-egypt

29. https://www.djb.de/Kom/K3/st16-17/

30. 'Ein nicht unerheblicher Teil der angezeigten Taten ist wahrscheinlichsoweit nach den in den Medien bekannt gewordenen Details eine Einschätzung überhaupt möglich ist—nach geltendem Recht gar nicht 
strafbar, weil die Taten entweder überraschend erfolgten und daher kein Widerstand seitens der Täter überwunden werden musste oder aber die Taten gar nicht als „erheblich“i.S.d. Strafrechts eingeordnet werden.' (Stellungnahme des DJB zur öffentlichen Anhörung des Ausschusses fuer Frauen, Gleichstellung und Emanzipation des Landtags Nordrhein Westphalen am 29.Juni 2016, Reform des Sexualstrafrechts).

31. '[E]in qualifiziertes Nötigungsmittel, nämlich Gewalt, Drohung mit gegenwärtiger Gefahr für Leib und Leben oder das nötigende Ausnutzen einer schutzlosen Lage, in der das Opfer aufgrund der Schutzlosigkeit keinen Widerstand leistet'. Cited in Landtag Nordrheinwestphalen, 16. Wahlperiode (Vorlage 16/3733).

32. https:/www.djb.de/Kom/K3/pm16-03/

33. https://www.bundesrat.de/SharedDocs/drucksachen/2016/01010200/162-16.pdf?_blob=publicationFile\&v=1

34. http://www.zeit.de/gesellschaft/zeitgeschehen/2016-06/rechtspolitiksexualstrafrecht-nein-heisst-nein-fischer-im-recht/seite-3

35. This kind of mass attack also happened in other European countries, in cities such as Zurich and Stockholm.

\section{References}

Abdelmonem, A., Bavelaar, R. E., Wynee-Hughes, E., \& Galán, S. (2016). The "Taharrush" Connection: Xenophobia, Islamophobia and Sexual Violence in Germany and Beyond. Retrieved March 12, 2016, from http://religionresearch.org/closer/2016/03/12/the-taharrush-connection-xenophobiaislamophobia-and-sexual-violence-in-germany-and-beyond/

Ali, P. A., \& Naylor, P. B. (2013). Intimate Partner Violence: A Narrative Review of the Biological and Psychological Explanations for Its Causation. Aggression and Violent Behavior, 18, 373-382.

Amnesty International. (2015). 'Circles of Hell'-Domestic, Public and State Violence Against Women in Egypt. Index: MDE 12/004/2015.

Bates, E. A., Graham-Kevan, N., \& Archer, J. (2014). Testing Predictions from the Male Control Theory of Men's Partner Violence. Aggressive Behavior, 40, 42-55. Cavanaugh, M. M. (2012). Theories of Violence: Social Science Perspectives. Journal of Human Behavior in the Social Environment, 22(5), 607-618.

Craun, S. W., \& Theriot, M. T. (2009). Misperceptions of Sex Offender Perpetration Considering the Impact of Sex Offender Registration. Journal of Interpersonal Violence, 24, 2057-2072. 
Fekete, L. (2004). Anti-Muslim Racism and the European Security State. Race \& Class, 46(1), 3-29.

Fraser, N. (1990). Rethinking the Public Sphere: A Contribution to the Critique of Actually Existing Democracy. Social Text, (25/26), 56-80. https://doi. org/10.2307/466240

Garner, S., \& Salod, S. (2015). The Racialisation of Muslims: Empirical Studies to Islamophobia. Critical Sociology, 41(1), 9-19.

Goldberg, D. T. (1993). Racist Culture: Philosophy and the Politics of Meaning. Hoboken, NJ: Wiley.

Goldberg, D. T. (2002). The Racial State. Cambridge: Cambridge University Press.

Kern, S. (2016, March 5). Germany: Migrant Rape Crisis Worsens-Public Spaces Are Becoming Perilous for Women and Children. Retrieved from https://www. gatestoneistitute.org/7557/germany-rape-migrants-crisis

Mancini, C., \& Pickett, J. T. (2016). The Good, the Bad and the Incomprehensible: Typifications of Victims and Offenders as Antecedents of Beliefs About Sex Crime. Journal of Interpersonal Violence, 31(2), 257-281.

McDowell, L. (1983). Towards and Understanding of the Gender Division of Urban Space. Environment and Planning D: Society and Space, 1, 59-72.

Morgan, G., \& Poynting, S. (Eds.). (2013). Global Islamophobia: Muslims and Moral Panic in the West. London: Ashgate.

Nelson, C. (2015). The Domestic Is Political, and the Political Is Gendered: An Analysis of Veiled Subjects, Gendered Epistemologies and Muslim Bodies. Islamophobia Studies Journal, 3(1), 106-114.

Šeta, D. (2016). Forgotten Women: The Impact of Islamophobia on Muslim Women. Brussels: ENAR, European Network Against Racism.

Turchik, J. A., Hebenstreit, C. L., \& Judson, S. S. (2016). An Examination of the Gender Inclusiveness of Current Theories of Sexual Violence in Adulthood: Recognizing Male Victims, Female Perpetrators, and Same-Sex Violence. Trauma, Violence, \& Abuse, 17(2), 133-148.

Vieten, U. M. (2007). Situated Cosmopolitanisms: The Notion of the Other in Discourses of Cosmopolitanism in Britain and Germany. PhD Thesis, University of East London, UK.

Vieten, U.M.(2011). Tackling the Conceptual Order of Multiple Discrimination. Situating Different and Difficult Genealogies of Race and Ethnicity. In D. Schiek \& A. Lawson (Eds.), European Union Non-Discrimination Law and Intersectionality. Investigating the Triangle of Racial, Gender and Disability Discrimination (pp. 63-76). Farnham: Ashgate. 
Vieten, U. M. (2012). Gender and Cosmopolitanism in Europe: A Feminist Perspective. Farnham: Ashgate.

Vieten, U. M. (2016). Notions of Conflict and "New" Citizens' Inclusion: PostCosmopolitan Contestations in Germany. In U. M. Vieten \& G. Valentine (Eds.), Cartographies of Differences-Interdisciplinary Perspectives (pp. 109-134). Bern: Peter Lang Publishers.

Vieten, U. M. (2017). Far Right Populism and Women: The Normalization of Gendered Anti-Muslim Racism and Gendered Culturalism in the Netherlands. Journal of Intercultural Studies, 37(6), 621-636.

Walby, S., Towers, J., \& Francis, B. (2014). Mainstreaming Domestic and Gender-Based Violence into Sociology and Criminology of Violence. The Sociological Review, 62(2), 187-214.

Wodak, R. (2013). "Anything Goes!"-The Haiderization of Europe. In R. Wodak, M. KhosraviNik, \& B. Mral (Eds.), Right-Wing Populism in Europe-Politics and Discourse (pp. 23-37). London: Bloomsbury Publishing. Wodak, R., \& Reisigl, M. (2015). Discourse and Racism. In D. Tannen, H. E. Hamilton, \& D. Schiffrin (Eds.), The Handbook of Discourse Analysis (pp. 576-596). Chichester: Blackwell.

Wolfgang, M. E., \& Ferracuti, F. (1967). The Subculture of Violence: Towards and Integrated Theory of Criminology. London: Tavistock Publications.

Yilmaz, F. (2015). From Immigrant Worker to Muslim Immigrant: Challenges for Feminism. European Journal of Women's Studies, 22(1), 37-52. 